\title{
The Influence of Pocketbook to Improve Student Learning Outcomes and Motivation on Electron Configuration Material
}

\author{
Nurdiyati Abdullah'1, Ibnu Khaldun², Musri Musman²* \\ ${ }^{1}$ Science Education Study Program, Postgraduate Program at Syiah Kuala University, Banda Aceh, Indonesia \\ ${ }^{2}$ Chemistry Education Study Program, FKIP, Syiah Kuala University, Banda Aceh, Indonesia
}

\section{DOI: $\underline{10.29303 / \text { ippipa.v7i3.647 }}$}

\section{Article Info}

Received: February 26th 2021

Revised: May 6 ${ }^{\text {th }}, 2021$

Accepted: May 24th, 2021

\begin{abstract}
This study aims to determine the increase in motivation and learning outcomes of students on the use of pocketbooks. This type of research is a quasi-experiment which was carried out with a nonequivalent control group design. The population in this study were students of class X SMA Negeri 3 Banda Aceh with 66 samples selected by random sampling, data obtained through test questions, and questionnaires. The learning outcome data were analyzed by using the $t$ test. It shows that there is an effect of the pocketbook on the learning outcomes of the experimental class with the control. The N-gain of the experimental class was 63.09 with a fairly effective value category, while the control class was 46.58 . Pocketbook also affects learning motivation with the $\mathrm{N}$-gain of the experimental class at 41.48 , while the control class is 32.01 .
\end{abstract}

Keywords: Learning outcomes; motivation; pocketbook; quasi experiment; random sampling

Citation: Abdullah, N., Khaldun, I., \& Musman, M. (2021). The Influence of Pocketbook to Improve Student Learning Outcomes and Motivation on Electron Configuration Material. Jurnal Penelitian Pendidikan IPA, 7(3), $298-304$. doi:https://doi.org/10.29303/ippipa.v7i3.647

\section{Introduction}

Learning online is one of the recommendations of the Ministry of Education and Culture in the face of the Covid-19 pandemic. Online implementation can be done using a platform that can help the teaching and learning process, for example google meet, zoom meeting, and whatsap (Handarini \& Wulandari, 2020) (Lestari \& Siskandar, 2021). One school that implements online learning is SMA Negeri 3 Banda Aceh, which has a low chemical value, especially in the electron configuration material.

Based on the results of an interview with a chemistry teacher at SMA Negeri 3 Banda Aceh, it was stated that students had difficulty learning chemistry, one of which was the electron configuration. Some of the factors that cause difficulties in studying the electron configuration include the textbook used which is relatively large in size so it is difficult to carry, the reading description on each page is relatively long, and the explanation is difficult to understand. These difficulties affect the motivation to learn. Students who have high learning motivation will find it easier to take part in learning, on the other hand, low motivation appears not to be enthusiastic so they have difficulty understanding the concept and learning process (Puspitorini et al., 2014). Low motivation in learning results in not optimal learning outcomes.

Data on the results of the national exams (UN) for the last three years, namely $53.09 \%$ for the 2017 school year, $51.93 \%$ in 2018, and in 2019 with a percentage of $36.28 \%$ (Puspendik, 2019). Based on observations that have been made further it can be seen from the data the average value of daily tests is 43.76 compared to the minimum completeness criteria value 
of 76. Based on the data above shows the learning outcomes of students at SMA Negeri 3 Banda Aceh on low electron configuration material.

The learning success of students can be influenced by several factors, both internal factors such as intelligence, talents, interests, and learning motivation. External factors include the school environment, family, and community (Ardila \& Hartanto, 2017). Motivation has a positive influence on the achievement of learning outcomes (Lin et al., 2017; Hanim et al., 2017).

Students will be motivated in learning if there is an appropriate and interesting learning media available (Anggraeni \& Aisyah, 2016). Pocketbook media can increase learning motivation, because it has a positive influence where students are interested in reading, easy to carry everywhere, an attractive appearance equipped with pictures and colors, thus fostering student motivation to study the material in the pocketbook (Nurhayati, 2019). Students who do not have motivation to learn will show an unenthusiastic attitude and do not want to know about the subject matter (Jami, 2020).

Chemical matter consists of a combination of abstract calculations or concepts. Concepts in chemistry are interrelated between one material and another, so a correct basic understanding and high intellectual ability are needed (Mahfuzah et al., 2018). Chemistry courses require graphics to explain abstract concepts including electron configuration materials. Students have difficulty connecting between atomic structures (including shells, subshells, and orbitals) associated with energy levels and quantum numbers. This relationship is used to determine periods and groups based on quantum numbers or electron configurations (Karjono, 2018). Understanding abstract material requires the use of an appropriate medium (Juniarni et al., 2019)

Media innovation can increase motivation and learning outcomes (Dewi et al., 2019). The media is expected not only to make students understand the meaning of a term in the material, but also to train skills to solve the given problem (Maharani et al., 2020). In addition, learning media must also be systematically arranged with the aim of making it easier for students to learn so that it can increase the success of the learning process (Ramdoniati et al., 2019). Indicators of good learning media are easy to understand, easy to use and able to stimulate the activeness of students (Yulyani, 2020). The application of learning media can improve learning outcomes much higher than conventional learning (Taufiq et al., 2014).

Configuration material can be completed using alternatives including media, one of which is a pocketbook. Purwati et al. (2016), stated that pocketbooks are small books that are easy to carry, compact, lightweight, can be stored in a pocket making it easier to study anywhere, and provide fun for students. Pocketbook has the advantage of a more concise number of pages so students can get information quickly without wasting time. Its characteristics can also stimulate and increase learning motivation so that students become more enthusiastic about following the explanation from the teacher (Wulandari et al., 2016).

Previous research regarding the use of pocketbooks has been conducted by several researchers. Pocketbooks can increase students' responses to science learning (Zukmadini et al., 2018), increase knowledge (Mona \& Azalea, 2018), increase conceptual understanding (Winarto et al., 2018), are effective in increasing knowledge and attitudes (Sofiana \& Ayu , 2017). Research conducted by Indianasari et al. (2019), concluded that pocketbooks are also one of the media that can be used as supporting teaching materials to attract students 'attention and interest and can develop students' potential to become independent learners in learning.

\section{Method}

This study used a quasi experimental method with a nonequivalent control group design. The place of research was conducted at SMA Negeri 3 Banda Aceh. The population in this study were all students of class X MIPA SMA Negeri 3 Banda Aceh with a total of 228 students from 7 classes. The sample of 66 people in this study came from class $X$ MIPA 6 as the experimental class, and class X MIPA 4 as the control class. Sampling was random sampling. The data analysis technique was carried out by testing for normality, homogeneity and hypothesis.

\section{Result and Discussion}

\section{Student Learning Outcomes}

Covid-19 has caused educational institutions to change face-to-face learning into online learning (Garad et al., 2021). Yulyani (2020), states that online learning is a learning system that is not face to face but uses a platform that can help the teaching and learning process. The online learning media platform used in SMA Negeri 3 is Microsoft 365. During the learning process, parents supervise their children in learning. The test is an indicator of the success or failure of students in the learning activities carried out (Hartina et al., 2020). The pretest was carried out to see initial abilities and was carried out online by distributing links to students through the chat menu on Microsoft 
365. The link contains questions and motivational questionnaires that must be answered by students. Final proficiency tests are also carried out in a similar manner.
The pretest and posttest results were processed using SPSS. The data is processed to determine normality, homogeneity, and hypothesis tests. The results of the data obtained are presented in Table 1.

Table 1. The results of the normality, homogeneity, and hypothesis testing of learning outcomes

\begin{tabular}{|c|c|c|c|c|c|c|}
\hline \multirow{2}{*}{ No } & \multirow{2}{*}{ Classes } & \multirow{2}{*}{ Normality } & \multirow{2}{*}{ Homogeneity } & \multicolumn{2}{|l|}{ t-test } & \multirow{2}{*}{ Declaration } \\
\hline & & & & $t_{\text {count }}$ & $t_{\text {table }}$ & \\
\hline 1 & Experiment & 0.200 & 0.816 & 3.276 & 1.998 & There are significant differences \\
\hline 2 & control & 0.200 & 0.816 & 3.276 & 1.998 & There are significant differences \\
\hline
\end{tabular}

Table 1 shows that the normality test is carried out to determine whether the data obtained is normally distributed or not. The normality test was carried out on the pretest, posttest and $\mathrm{N}$-gain values of the experimental and control classes using the Kolmogorov-Smirnov test. Data is normally distributed if the $p$-value is $>0.05$ significant level. The value obtained is $0.200>0.05$, it can be concluded that the data is normally distributed. Homogeneity test used the Levene test with a significant level of 0.05 . Obtaining a value of $a>0.05$, it can be concluded that the data is homogeneous.

The homogeneity of the learning outcomes of students in the experimental and control classes was 0.816 so that the data was homogeneous. Hypothesis testing to determine the increase in learning outcomes using the $t$ test. The results obtained state that $t_{\text {count }}>$ $t_{\text {table }}$ with $t_{\text {count }}$ is 3.276 and $t_{\text {table }}$ is 1.998 . Hypothesis testing in this study shows that there are significant differences between the experimental and control classes.

Furthermore, the N-gain is calculated which aims to determine the increase in student learning outcomes between the experimental class and the control. The average score of student learning outcomes can be seen in Figure 1.

Based on Figure 1, students experience an increase in learning outcomes before and after learning. This increase can be seen based on the $\mathrm{N}$-gain data between the experimental class of 63.09 which is categorized as quite effective while the control is less effective (Hake, 1999). This shows that the increase in learning outcomes in the experimental class is better than the control.

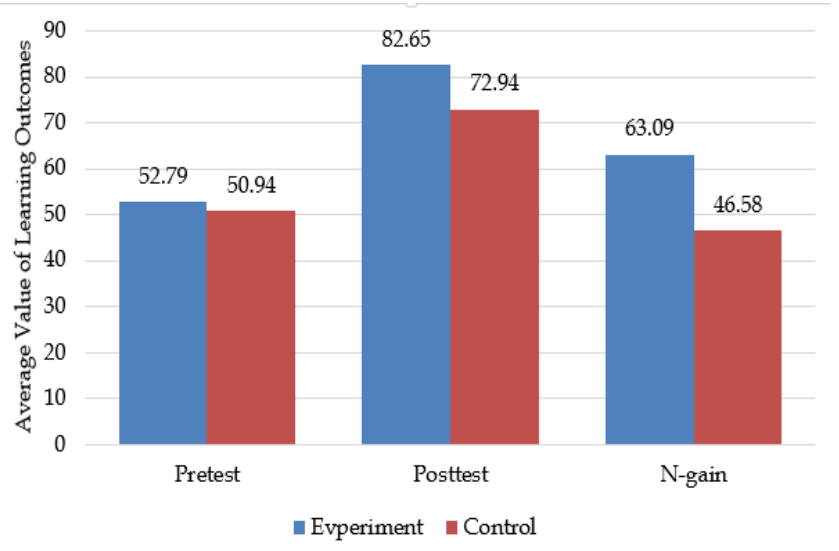

Figure 1. Graph of the average pretest, posttest and N-gain

The increase in learning outcomes is higher in the experimental class than the control, due to differences in treatment. The experimental class used a pocketbook, while the control only used the students' handbook. The use of learning media such as pocketbooks can improve student learning outcomes because the contents of the book are concise, easy to understand, supported by pictures, and the language presented makes it easier for students to learn the material (Widodo \& Wiyatmo, 2017); Cahyana et al., 2017). This opinion is also supported by Asyhari \& Silvia (2016), the results of the responses of students stated that it is easier for them to understand the material written on the pocketbook compared to the textbooks they usually use. These advantages result in students being active in learning so that their learning outcomes can increase.

Pocketbook has an effect on improving learning outcomes. Students who use pocketbooks when learning are proven to have improved learning outcomes compared to students who only learn with textbooks. This is supported by the statement (Khulafa \& Santosa, 2018), that pocketbooks can increase student learning outcomes from 46 to $97 \%$, so it can be concluded that pocketbooks are suitable for use in the learning process. Mona \& Azalea (2018), state that pocketbooks show a significant increase in knowledge. Cahyono et al. (2018), said that pocketbooks are a source of learning to attract attention and interest in 
learning, so that students' learning achievement can increase. Trisianawati et al. (2017), also stated that there were significant differences and better learning outcomes than classes using pocketbooks and using regular textbooks. As for a few pictures part of the pocketbook design electron configuration materials for more details are presented in Figure 2.

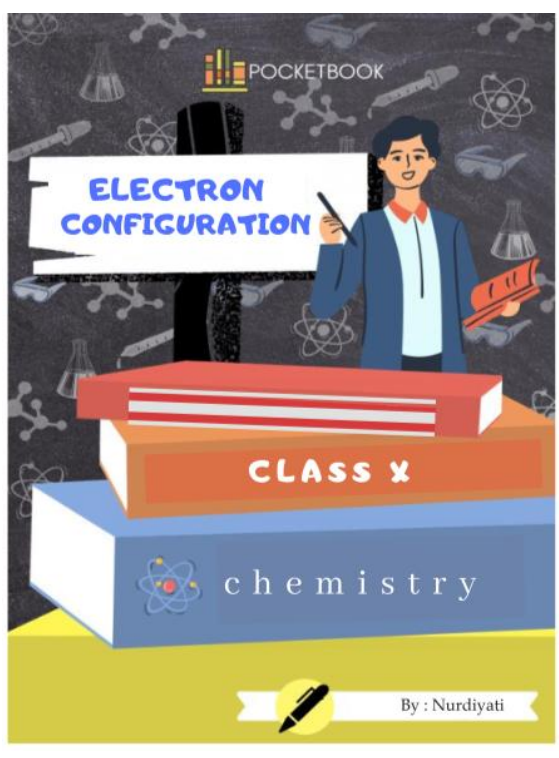

(a)

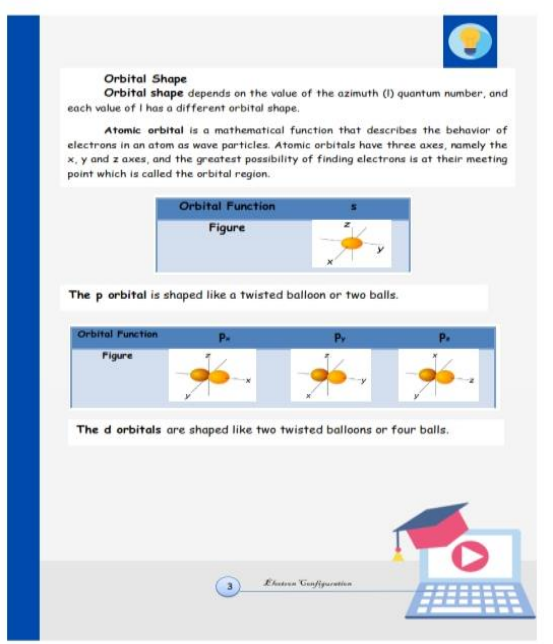

(d)

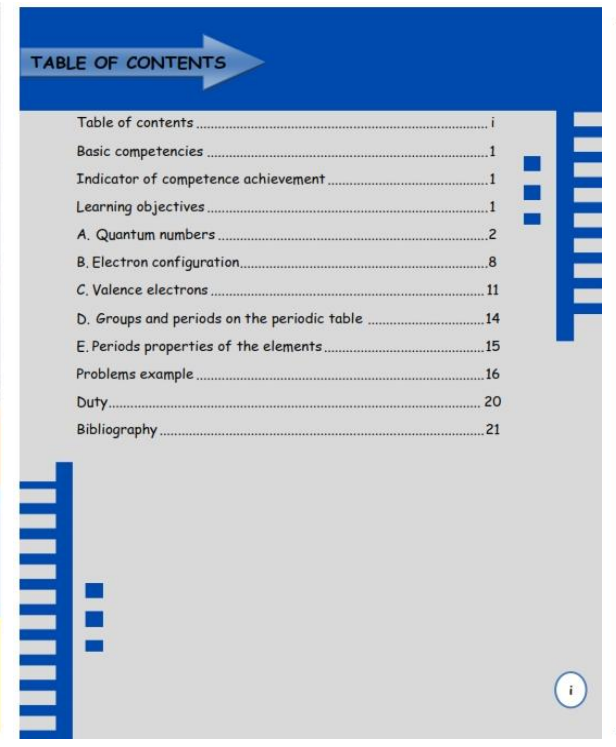

(b)

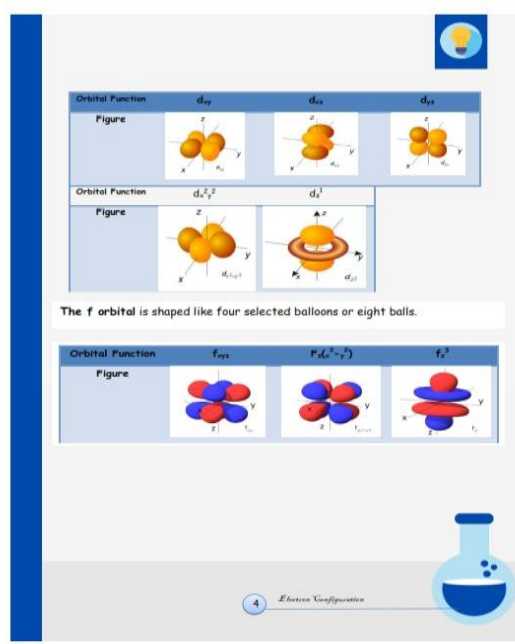

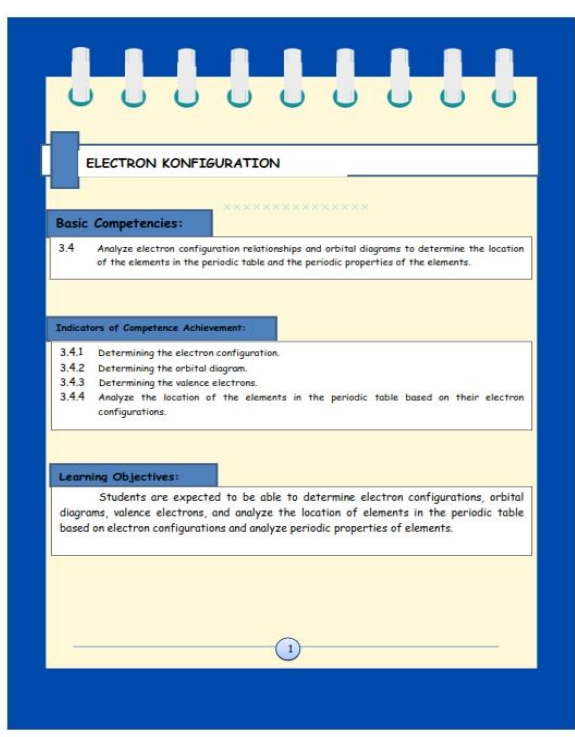

(c)

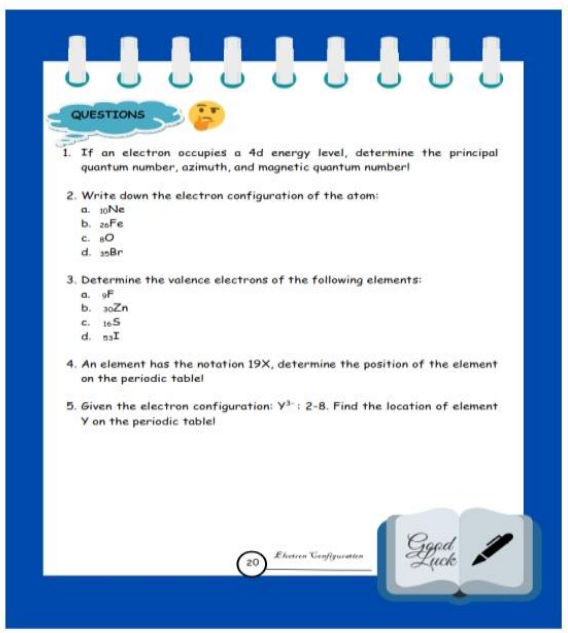

(e)

Figure 2. Description of pocketbook design for students; (a) cover, (b) table of contents, (c) basic competencies, indicators of competence achievement, learning objectives, (d) electron configuration material, (e) questions

\section{Students' Learning Motivation}

Initial and final motivation results data were processed using SPSS. The tests carried out include normality, homogeneity, and hypothesis tests. The results of the data obtained are presented in Table 2.

Table 2. The results of the normality, homogeneity, and hypothesis testing of learning motivation

\begin{tabular}{llllcll}
\hline No & \multicolumn{1}{c}{ Classes } & Normality & Homogeneity & \multicolumn{2}{c}{$\mathrm{T}$ test } & Declaration \\
\cline { 4 - 5 } & & & $\mathbf{T}_{\text {count }}$ & $\mathbf{t}_{\text {table }}$ & \\
\hline 1 & Experiment & 0.182 & 0.591 & 2.017 & 1.998 & There are significant differences \\
2 & Control & 0.200 & 0.591 & 2.017 & 1.998 & There are significant differences \\
\hline
\end{tabular}


Normality test to find out the initial and final motivation values are normally distributed or not. The normality test was carried out on the values obtained in the experimental and control classes. The data is normally distributed if the $p$ value is $>0.05$ significance level. Based on Table 2, the pvalue obtained is 0.182 in the experimental class, while the control is 0.200 , it can be concluded that the data is normally distributed. The homogeneity test is carried out to see whether the data is homogeneous or not. The data obtained was 0.591> 0.05 , it was concluded that the data was homogeneous. Furthermore, the hypothesis is tested using the $t$ test. The results of the analysis using the $t$ test obtained tcount obtained for 2.017 while ttable 1.998, meaning that $\mathrm{t}$ count $>\mathrm{t}$ table, it can be concluded that the learning motivation between the experimental and control classes has a significant difference. Hypothesis testing criteria if $t_{\text {count }}>t_{\text {table }}$ then Ho is rejected, meaning that there is an influence on students' learning motivation before and after learning using a pocketbook.

Learning motivation data were obtained from questionnaires that were distributed to students before and after learning. The results of the data analysis of students' early and late learning motivation can be seen in Figure 2. The initial motivation before learning using a pocketbook in the experimental class was 61.21 , while the control score was 63.80 . The final motivation of students after learning in the experimental class increased by 76.98 , while in the control it was 74.94 . This shows that the use of pocketbook media that is applied to the experimental class has an effect on learning motivation can be seen in Figure 3.

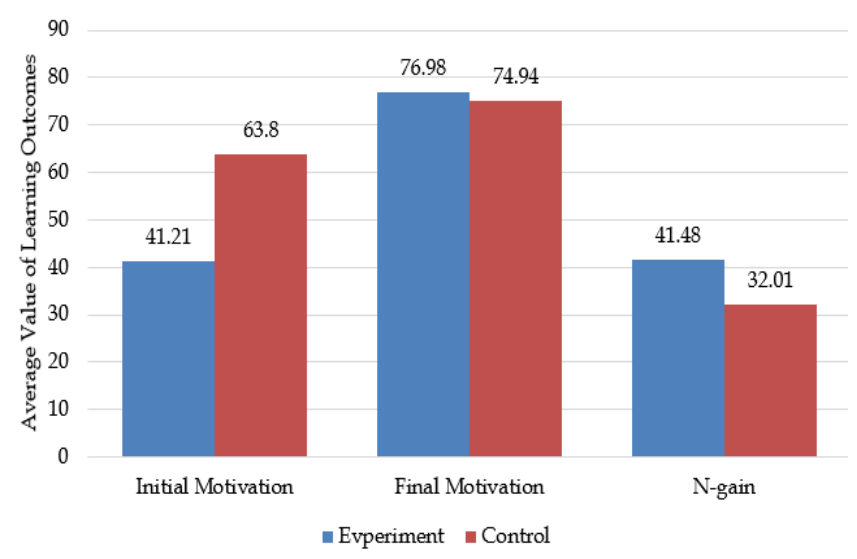

Figure 3. Data on early and late learning motivation using a pocketbook

Based on Figure 2, the learning motivation of students has increased, it can be seen that the $\mathrm{N}$-gain of the experimental and control classes is 41.48 and 32.01. This proves that the $\mathrm{N}$-gain of the experimental class is greater than the control. The increase in student motivation in the experimental class is better than the control. Retno et al., (2015) stated that the use of pocketbooks can increase learning motivation. This is because pocketbooks can make students learn independently, creatively, effectively, and efficiently (Mashita \& Komalasari, 2016).

Presentation of material in a concise pocketbook makes students immediately know the essence of the information. Pocketbooks have characteristics that can stimulate and increase motivation to learn. Students become more enthusiastic about following the explanation from the teacher. Learning media that are practical and not boring provide fun learning nuances so that students are more interested in taking part in learning (Wulandari et al., 2016).

Pocketbooks have many advantages including being able to support students' understanding and provide a pleasant learning atmosphere, easy to carry anywhere, attractive appearance equipped with pictures and colors, and being able to make students focus on learning so that it fosters student motivation to study the material in the pocketbook (Sari et al. al., 2019; Nurhayati, 2019).

\section{Conclusion}

Based on the results of the research and data analysis that has been done, it can be concluded that there is an effect of the pocketbook on the learning outcomes of the experimental class with the control. The N-gain of the experimental class was 63.09 with a fairly effective value category, while the control class was 46.58. Pocketbook also affects learning motivation with the N-gain of the experimental class at 41.48 , while the control class is 32.01 .

\section{References}

Anggraeni, Y., \& Aisyah, M. N. (2016). Pengembangan media pembelajaran pocket book untuk meningkatkan motivasi belajar siswa pada pelajaran pam. Kajian Pendidikan Akuntansi Indonesia, 5(2), 1-10. [Indonesian]

Ardila, A., \& Hartanto, S. (2017). Faktor yang memepengaruhi rendahnya hasil belajar matematika siswa MTS Iskandar Muda Batam. PYTHAGORAS: Journal of the Mathematics Education Study Program, 6(2), 175-186. doi:https://doi.org/10.33373/pythagoras.v6i2.9 66. [Indonesian]

Asyhari, A., \& Silvia, H. (2016). Pengembangan media pembelajaran berupa buletin dalam bentuk buku saku untuk pembelajaran IPA terpadu. Jurnal Ilmiah Pendidikan Fisika Al-Biruni, 5(1), 1-13. doi: 
https://doi.org/10.24042/jpifalbiruni.v5i1.100. [Indonesian]

Cahyana, U., Paristiowati, M., Savitri, D. A., \& Hasyrin, S. N. (2017). Developing and application of mobile game based learning (M-GBL) for high school students performance in chemistry. EURASIA Journal of Mathematics, Science and Technology Education, 13(10), 7037-7047. doi:https://doi.org/10.12973/ejmste/78728

Cahyono, B., Tsani, D. F., \& Rahma, A. (2018). Pengembangan buku saku matematika berbasis karakter pada materi trigonometri. Jurnal Phenomenon, 8(2), 185-199. [Indonesian]

Dewi, R. K., Wardani, S., Wijayati, N., \& Sumarni, W. (2019). Demand of ICT-based chemistry learning media in the disruptive era. International Journal of Evaluation and Research in Education, 8(2), 265270.

Garad, A., Al-Ansi, A. M., \& Qamari, I. N. (2021). The role of e-learning infrastructure and cognitive competence in distance learning effectiveness during the covid-19 pandemic. Jurnal Cakrawala Pendidikan, 40(1), 81-91. https://doi.org/10.21831/cp.v40i1.33474

Handarini, O. I., \& Wulandari, S. S. (2020). Pembelajaran daring sebagai upaya study from home (SFH) selama pandemi covid 19. Jurnal Pendidikan Administrasi Perkantoran (JPAP), 8(3), 496-503. [Indonesian]

Hanim, F., Suyanti, R. D., \& Harahap, F. (2017). The effect of students' worksheet based on skill of science and motivation process toward learning outcomes at grade 4 SD Negeri 164330 Tebing Tinggi. Journal of Research \& Method in Education (IOSR-JRME), 7(5), 57-61.

Hartina, L., Rosidin, U., \& Suyatna, A. (2020). Pengaruh penerapan instrumen performance assessment pada pembelajaran IPA berbasis laboratorium real terhadap hasil belajar siswa. Jurnal Penelitian Pendidikan IPA, 6(1), 25-31. doi: https://doi.org/10.29303/jppipa.v6i1.299

Indianasari, Suharini, E., \& Handoyo, E. (2019). Effectiveness of problem base learning (PBL) assisted by pocket book to reading literacy skill of students. Educational Management, 8(2), 214220.

Jami, J. (2020). Analysis of student learning motivation in chemical learning. Jurnal Penelitian Pendidikan IPA, 5(1), 30-34. doi: https://doi.org/10.26740/jppipa.v5n1.p30-34

Juniarni, D. I., Fadhilah, R., \& Kurniawan, R. A. (2019). Pengembangan permainan lego kimia sebagai media pembelajaran sub materi konfigurasi elektron pada siswa Kelas X SMA Muhammadiyah 1 Pontianak. AR-RAZI Jurnal
Ilmiah, $\quad 7(1), \quad 47-55 . \quad$ doi: https://doi.org/10.29406/ar-r.v7i1.1381. [Indonesian]

Karjono, M. T. (2018). Penggunaan tabel MT kuantum untuk meningkatkan hasil belajar siswa pada materi struktur atom dan sistem periodik di Kelas X MIPA 5 SMAN 1 Tanjung Pinang. Jurnal Zarah, 6(1), 6-12. doi: https://doi.org/10.31629/zarah.v6i1.295 [Indonesian]

Khulafa, F. N., \& Santosa, P. (2018). The developmet of pocket book as learning media to make batik jumput in multicultural arts and scarf subject. Asia Pacific Journal of Contemporary Education and Communication Technology, 4(1), 51-57. doi: https://doi.org/10.25275/apjcectv4i1edu6

Lestari, H., \& Siskandar, R. (2021). Cultivating green behavior of eco literation-based elementary school students during the covid-19 pandemic. Jurnal Penelitian Pendidikan IPA, 7(1), 49-53. doi: https://doi.org/10.29303/jppipa.v7i1.477

Lin, M. H., Chen, H. C., \& Liu, K. S. (2017). A study of the effects of digital learning on learning motivation and learning outcome. EURASIA Journal of Mathematics, Science and Technology Education, 13(7), 3553-3564. doi: https://doi.org/10.12973/eurasia.2017.00744a

Maharani, R. J. P., Taufik, M., Ayub, S., \& Rokhmat, J. (2020). Pengaruh model pembelajaran inkuiri dengan bantuan media tiga dimensi terhadap keterampilan proses sains dan hasil belajar fisika peserta didik. Jurnal Penelitian Pendidikan IPA, 6(1), $113 . \quad$ doi: https://doi.org/10.29303/jppipa.v6i1.326. [Indonesian]

Mahfuzah, B. A., Munzil, M., \& Utomo, Y. (2018). Efektivitas GDL (guided discovery learning) dan problem solving terhadap KBK (keterampilan berpikir kritis) dan HOTS (higher order thingking skills). Jurnal Pendidikan: Teori, Penelitian, dan Pengembangan, 3(6), 739-744. doi: https://doi.org/10.17977/jptpp.v3i6.11131. [Indonesian]

Mashita, M., \& Komalasari, K. (2016). Efektivitas penggunaan media buku saku dalam pembelajaran pendidikan kewarganegaraan untuk menumbuhkan cinta budaya daerah siswa. Modeling: Jurnal Program Studi PGMI, 3(1), 21-37. [Indonesian]

Mona, D., \& Azalea, F. W. (2018). Leaflet and pocketbook as an education tool to change level of dental health knowledge. Bali Medical Journal, $7(3), \quad 760-763 . \quad$ doi: https://doi.org/10.15562/bmj.v7i3.1172. [Indonesian] 
Nurhayati, E. (2019). Penerapan buku saku dengan pendekatan saintifik untuk meningkatkan motivasi dan hasil belajar siswa pasca gempa bumi. Jurnal Kependidikan: Jurnal Hasil Penelitian dan Kajian Kepustakaan di Bidang Pendidikan, Pengajaran dan Pembelajaran, 5(2), 94-99. doi: https://doi.org/10.33394/jk.v5i2.1804.

[Indonesian]

Purwati, P., Qurbaniah, M., \& Fadhilah, R. (2016). Pengaruh metode pemecahan masalah berbantuan buku saku terhadap hasil belajar pada materi pokok stoikiometri di kelas X SMA Negeri 1 Sungai Raya. AR-RAZI Jurnal Ilmiah, 4(2), 109-117. doi: https://doi.org/10.29406/arz.v4i2.680.

[Indonesian]

Puspitorini, R., Prodjosantoso, A. K., Subali, B., \& Jumadi, J. (2014). Penggunaan media komik dalam pembelajaran IPA untuk meningkatkan motivasi dan hasil belajar kognitif dan efektif. Jurnal Cakrawala Pendidikan, 33(3). doi: https://doi.org/10.21831/cp.v3i3.2385.

[Indonesian]

Ramdoniati, N., Muntari, M., \& Hadisaputra, S. (2019). Pengembangan bahan ajar kimia berbasis problem based learning untuk meningkatkan keterampilan metakognisi. Jurnal Penelitian Pendidikan IPA, 5(1). doi: https://doi.org/10.29303/jppipa.v5i1.148.

[Indonesian]

Retno, A. T. P., Saputro, S., \& Utami, B. (2015). Pengembangan media pembelajaran buletin dalam bentuk buku saku berbasis hirarki konsep untuk pembelajaran kimia kelas XI materi hidrolisis garam. Jurnal Pendidikan Kimia, 4(2), 74-81. [Indonesian]

Sari, W. M., Riswanto, R., \& Partono, P. (2019). Validitas mobile pocket book berbasis android menggunakan adobe flash pada materi suhu dan kalor. Berkala Ilmiah Pendidikan Fisika, 7(1), 35-42. doi: https://doi.org/10.20527/bipf.v7i1.5728. [Indonesian]

Sofiana, L., \& Ayu, S. M. (2017). Pocket book to enhance knowledge and attitude regarding prevention of soil-transmitted helminth. International Journal of Evaluation and Research in Education (IJERE), 6(3), 252-256.

Taufiq, M., Dewi, N. R., \& Widiyatmoko, A. (2014). Pengembangan media pembelajaran IPA terpadu berkarakter peduli lingkungan tema "konservasi" berpendekatan science edutainment. Jurnal Pendidikan IPA Indonesia, $3(2)$. doi: https://doi.org/10.15294/jpii.v3i2.3113. [Indonesian]
Trisianawati, E., Djudin, T., \& Katihada, T. (2017). Penyediaan bahan bacaan berupa buku saku untuk meningkatkan hasil belajar siswa SMP Negeri 5 Monterado. Jurnal Pendidikan Informatika Dan Sains, 6(2), 219-229. [Indonesian]

Widodo, A., \& Wiyatmo, Y. (2017). Pengembangan media pembelajaran buku saku digital berbasis android untuk meningkatkan minat dan hasil belajar fisika peserta didik kelas XI SMA N 1 Jetis pada materi pokok keseimbangan benda tegar. E-Journal Pendidikan Fisika, 6(2), 147-154. [Indonesian]

Winarto, W., Khiyarusoleh, U., Ardiyansyah, A., Wilujeng, I., \& Sukardiyono, S. (2018). Pocket book based on comic to improve conceptual understanding of child sex abuse (CSA): A case study of elementary school. International Journal of Instruction, 11(4), 889-900. doi: https://doi.org/10.12973/iji.2018.11456a

Wulandari, T., Prihandono, T., \& Handayani, R. D. (2016). Pengembangan pocket book sahabat IPA pada materi indra pendengaran dan sistem sonar di SMP. Jurnal Pembelajaran Fisika, 5(3), 277-284. [Indonesian]

Yulyani, R. D. (2020). Pengaruh media pembelajaran google classroom, fasilitas pembelajaran dan minat belajar mahasiswa terhadap motivasi belajar daring selama pandemi covid-19. EdHumanistics : Jurnal Ilmu Pendidikan, 5(2), 703-714. doi: https://doi.org/10.33752/edhumanistics.v5i2.1071 \. [Indonesian]

Zukmadini, A. Y., Jumiarni, D., \& Kasrina, K. (2018). Developing antimicrobial medicinal plants pocket book based on local wisdom of mukomuko and serawai ethnics. Jurnal Pendidikan Biologi Indonesia, 4(2), 95-104. doi: https://doi.org/10.22219/jpbi.v4i2.5436 